\title{
Friend or Foe?
}

The Diminishing Space of China's Civil Society

\section{Samson Yuen}

\section{OpenEdition \\ Journals}

\section{Electronic version}

URL: http://journals.openedition.org/chinaperspectives/6807

DOI: 10.4000/chinaperspectives.6807

ISSN: 1996-4617

\section{Publisher}

Centre d'étude français sur la Chine contemporaine

\section{Printed version}

Date of publication: 1 September 2015

Number of pages: $51-56$

ISSN: 2070-3449

Electronic reference

Samson Yuen, «Friend or Foe? », China Perspectives [Online], 2015/3 | 2015, Online since 01 January 2017, connection on 15 September 2020. URL : http://journals.openedition.org/chinaperspectives/ 6807

(c) All rights reserved 


\title{
CefC News Analysis
}

\section{Friend or Foe?}

\section{The Diminishing Space of China's Civil Society}

\author{
SAMSON YUEN
}

${ }^{\mathrm{p}} \mathrm{in}$ hina's civil society is under immense pressure. Since President Xi Jinping came to power in late 2012, Chinese authorities have cracked down on a score of civil society organisations, while hundreds of activists and dissidents have been detained, arrested, and sentenced to prison. Control over cyberspace has been further tightened, and a new commission has been established to oversee national security across a wide spectrum of issues. A campaign against "Western values" has been launched, and even the term "civil society" is becoming increasingly sensitive in public or classroom discussion. As the crackdown continues, one might wonder whether the fang/shou cycle, the alternating pattern of relaxation and control that unleashed China's "reform and opening up" in the 1980s and 1990s, is still applicable under Xi's China, where control (shou) has now become the norm and relaxation (fang) the exception. Previously, moderate or "issue-based" groups and activists, although under constant state surveillance, remained intact as long as they steered clear of a political agenda. An Economist article in April 2014 even argued that "a flourishing civil society is taking hold." (1) A year later, however, it has become questionable whether such an observation is still valid.

What are the implications for the development of China's civil society? This paper reviews recent crackdown efforts and new restrictions on civil society, and argues that these measures are diminishing the space for moderate and reformist NGOs and activists to negotiate their survival. It also shows that ad-hoc repression of civil society groups and activists is now moving towards a more systematic restriction of both foreign and domestic NGOs. While civil society is unlikely to disappear due to its resilience and its ability to adapt to barriers, there is little cause for optimism in the coming years.

\section{Rampant crackdown on civil society}

In the early days after Xi Jinping assumed office as China's president, the question of whether he was a liberal political reformer emerged among China observers. Yet the debate was brief and speculation was quickly dispelled. As Xi launched a rampant anti-corruption drive targeting both "tigers" and "flies," the successive downfall of high-ranking officials neither opened up room for public criticism of the government nor created space for grassroots civil society to expand and prosper. Instead, Xi ruled out political reform, emphasised cadres' adherence to the central leadership of the Party, and revived the "mass line" as a Maoist alternative to democracy so as to rebuild the Party's legitimacy among the masses. (2) In addition, Xi also warned against dangerous Western values that constitute ideological threats to China, highlighting seven ideas, including universal values, freedom of speech, and civil society, to be forbidden in public discussion. ${ }^{(3)}$ On the institutional level, Xi's administration founded at least two governmental organisations delegated with expansive power over Chinese society. The National Security Commission, established in early 2014, was made responsible for coordinating a range of national security tasks and making relevant policies, putting paramount importance on safeguarding state security. Meanwhile, a new Internet regulatory body, the Cyberspace Administration of China, was endowed with expanded powers to defend cybersecurity against both domestic and foreign threats.

Against the backdrop of a tightened political and ideological space under Xi's rule, the spate of crackdowns against civil society groups and activists came as no surprise. Several activists and opinion leaders were detained and arrested as early as 2013, the most prominent being Xu Zhiyong, a legal activist and the founder of the New Citizens' Movement (xin gongmin yundong 新公民运动), who was placed under house arrest in April 2013. Whereas Xu was sentenced to four years in prison in early 2014 for "disturbing public order," crackdown efforts on activists did not subside and even intensified. In May 2014, after a closed-door seminar held to commemorate the 25 th anniversary of June Fourth, at least 12 of the 16 participants, a group consisting of intellectuals and activists, were detained. (4) Although most of them were soon released, rights lawyer Pu Zhiqiang has remained under arrest ever since, and was formally charged with inciting ethnic hatred and "picking quarrels and provoking trouble" in May 2015. ${ }^{(5)}$ Another rights lawyer, Tang Jingling, a campaigner against graft and land seizures, was taken from his Guangzhou home ahead of the June Fourth anniversary, and was later charged with "inciting subver-

1. "Beneath the glacier," The Economist, 12 April 2014, www.economist.com/news/china/ 21600747-spite-political-clampdown-flourishing-civil-society-taking-hold-beneath-glacier (accessed on 19 July 2015).

2. Angela Meng, "Xi Jinping rules out Western-style political reform for China," South China Morning Post, 6 September 2014, www.scmp.com/news/china/article/1586307/xi-jinping-rules-out-western-style-political-reform-china (accessed on 19 June 2015); Sebastian Veg, "China's Political Spectrum under Xi Jinping," The Diplomat, 11 August 2014, http://thediplomat.com/2014/08/chinas-political-spectrum-under-xi-jinping (accessed on 19 June 2015).

3. Chris Buckley, "China Warns Officials Against 'Dangerous' Western Values," The New York Times, 13 May 2013, www.nytimes.com/2013/05/14/world/asia/chinese-leaders-warn-of-dangerouswestern-values.html (accessed on 19 June 2015).

4. Malcolm Moore, "China detains series of dissidents ahead of 25th anniversary of Tiananmen massacre," The Telegraph, 6 May 2014, www.telegraph.co.uk/news/worldnews/asia/china/10809825/ China-detains-series-of-dissidents-ahead-of-25th-anniversary-of-Tiananmen-massacre.html (accessed on 19 June 2015)

5. Emma Graham-Harrison, "Activist lawyer who defended Ai Weiwei charged with 'provoking trouble'," The Guardian, 15 May 2015, www.theguardian.com/world/2015/may/15/lawyer-puzhiqiang-ai-weiwei-charged-provoking-trouble-china (accessed on 19 June 2015) 
sion." "(6) The 71-year-old journalist Gao Yu was criminally detained in May for allegedly leaking state secrets to a foreign news site, and was later sentenced to seven years' imprisonment. In September 2014, Ilham Tohti, a Uyghur scholar and vocal advocate for minority rights detained since January 2014, was found guilty of separatism and handed a life sentence, the harshest treatment for a rights activist thus far. ${ }^{(7)}$ Then in October, dozens of mainland Chinese were detained for supporting Hong Kong's Occupy protests. ${ }^{\left({ }^{8}\right)}$ The scope of the civil society crackdown stretched beyond individual activists to civil society organisations. The Transition Institute, a moderately-positioned think-tank engaged in rights advocacy, was shut down by the authorities in July 2013. Its co-founder, Guo Yushan, who helped the blind activist Chen Guangcheng escape from house arrest, has been detained on the criminal charge of "provoking trouble" since October 2014. Another target was the Liren Rural Library, a chain library project aimed at providing children in underprivileged areas with free access to books. The NGO announced in September 2014 that all of its libraries across China would be closed down after repeated inspections and crackdowns by local authorities. ${ }^{(9)}$

A common thread that ran through these cases of repression was their engagement in certain areas of rights protection (weiquan 维权) and the involvement of reform-minded activists or intellectuals. The weiquan movement, which started around 2003, has been a recurrent target of repression for both central and local authorities. With the rampant ongoing repression under Xi's administration, however, the implication is that even moderate, depoliticised, and reformist civil society engagement without any stated political goals or intention to overthrow the Communist Party, which had been a strategy for many civic groups to maintain survival, is now running into a dead end.

In a 2012 article analysing government-NGO relationships in China, Wu Fengshi and Chan Kin-man use the concept of "graduated controls" (fenlei guanzhi 分类管治) to describe the state's differentiated approach on three types of NCOs, namely those involved in service delivery, those involved in service or advocacy in non-sensitive areas, and those involved in political/religious/ethnic or other sensitive areas. ${ }^{(10)}$ The authors argue that while the second category of NGOs did attract more attention from the supervising authorities and public security than the service delivery ones, they were given considerable breathing space and were not subject to constant crackdowns as were the third category. But as the Chinese government is adopting an increasingly militant approach towards civil society, the space for these mid-range NGOs might be disappearing, and the policy of "graduated controls," which gives rise to flexibility, might be gradually replaced by a friend-or-foe approach. One revealing example would be the Sunflower Women Workers' Centre (Xiangyanghua nügong huodong zhongxin 向阳花 女工活动中心) in Panyu, Guangdong Province, a grassroots NGO providing leisure activities for female migrant workers and occasionally engaging in rights defence activities. Despite initial support from the local authorities to promote migrant services when it successfully registered in 2012, the NGO has since been repeatedly harassed by thugs, forced to move by landlords, and most recently threatened with closure by local officials. ${ }^{(11)}$

The repression against NGOs is further entrenched by how local bureaucratic apparatuses implement the task of stability maintenance. As Hong Kong-based activist Zeng Jinyan argues based on the case of Guo Yushan, the tasks of "maintaining stability," especially for a younger generation of state security police, "has now become depoliticized, operationalized, routinized and commercialized." She attributes the problem to the goal-oriented nature of local authorities:
Instead of seeking solutions to real social problems, this product-oriented bureaucracy is geared only towards the perceived "quick fix" of suppression. Guided by this new methodology, the state security apparatus has no real interest in distinguishing the content and nature of different activists' work, their individual characteristics, the threat they pose to the regime or their level of cooperation with the state, nor are the police keen to weigh the impact of their arrest on the government's performance and public image. This new methodology has turned rights activists into standardized objects of business. ${ }^{(12)}$

Thus, even pragmatic, reformist NGOs and activists have become indiscriminate targets of repression. In the case of Liren, where the rationale for repression seemed less clear given that rural libraries are not politically sensitive from its outlook, the NGO's vast geographical coverage in remote regions might have alarmed the authorities for its potential reach across the heartland of China. As Gary King's finding on China's Internet control implies, the logic of censorship or stability maintenance lies not in the act and content itself, but rather in its reach and mobilisational potential. ${ }^{(13)}$

\section{The demise of issue-based activism: An overview}

\section{Environment}

Environmentalism has long enjoyed relative leniency as long as it remains within certain bounds. However, while a recent environmental documentary enjoyed a window of free discussion ahead of the annual "Two Sessions" (lianghui 两会), it was blocked after becoming too popular. The 103-minute documentary, entitled "Under the Dome" (Qiongding zhixia 穹頂之下), was produced by former CCTV news anchor Chai jing and was released on the Internet on 28 February 2015. Featuring a TED-talk presentation style and

6. "Rights lawyer Tang Jingling detained ahead of Tiananmen anniversary," South China Morning Post, 16 May 2014, www.scmp.com/news/china/article/1513444/rights-lawyer-tang-jinglingdetained-and-his-home-raided-ahead-tiananmen (accessed on 19 June 2015).

7. Laura Zhou, "Life in jail: Unusually harsh sentence for Uygur scholar Ilham Tohti for inciting separatism," South China Morning Post, 23 September 2014, www.scmp.com/article/1598567/ilhamtoht-sentenced-life-prison-pushing-uygur-independence?page=all (accessed on 19 June 2015).

8. Andrew Jacobs, "Chinese Authorities Make Arrests in Attempt to Prevent Pro-Democracy Campaigns on Mainland," The New York Times, 9 October 2014, www.nytimes.com/2014/10/10/ world/asia/chinese-authorities-make-arrests-in-attempt-to-prevent-pro-democracy-campaignson-the-mainland.html (accessed on 20 June 2015).

9. Vanessa Piao, "Rural Library Chain Closes, Citing 'Tremendous Pressure'," The New York Times Sinosphere Blog, 22 September 2014, http://sinosphere.blogs.nytimes.com/2014/09/22/rural-librarychain-closes-citing-tremendous-pressure (accessed on 20 June 2015); Song Zhibiao, "Chinese Government Moves to Limit and Eliminate Public Service NGOs: The Case of Liren Rural Libraries," China Change, 17 November 2014, http://chinachange.org/2014/11/17/chinese-governmentmoves-to-limit-and-eliminate-public-service-ngos-the-case-of-liren-rural-libraries (accessed on 19 June 2015).

10. Fengshi Wu and Kin-man Chan, "Graduated Control and Beyond: The Evolving Government-NGO Relations," China Perspectives, No. 2012/3, pp. 9-17.

11. Xiangyanghua nügong zhongxin (Sunflower Women Workers' Centre), 'Zisha' huo 'tasha': nü gong gongyi jigou yao xuanze yizhong sifa" (Suicide or murder: Female migrant NGO has to choose a way to die), 27 June 2015, http://mp.weixin.q9.com/s?_biz=MzlxOTAwNzkOMQ= $=\&$ mid $=213166659 \& i d x=1 \& s n=7 d c 1 e b 419 e 3 f c 16 c 09 c f 9 e 9836614 c f a \& s c e n e=5 \#$ rd (accessed on 2 July 2015).

12. Zeng Jinyan, "Guo Yushan and the predicament of NGOs in China," Probe International, 21 May 2015, http://journal.probeinternational.org/2015/05/21/guo-yushan-and-the-predicament-ofngos-in-china (accessed on 4 July 2015).

13. Gary King, Jennifer Pan, and Margaret E. Roberts, "How censorship in China allows government criticism but silences collective expression," American Political Science Review, Vol. 107, No. 2, 2013, pp. 326-343. 
using a variety of video footage, scientific data, and interviews with researchers and government officials, the documentary identified the wide usage of fossil fuels and the lack of government oversight as the primary causes behind the heavy smog in China. Although the film did not attack the Chinese political system as a whole, it drew attention to the role of state-owned oil companies in setting the country's lagging fuel standards and called for government action in regulating polluters and improving air quality. Within three days of its release, the film was viewed more than 150 million times on major Chinese video portals such as Tencent and Youku, and prompted 280 million posts on the microblogging site Sina Weibo. ${ }^{(14)}$

Its phenomenal success became a sudden and rare opening for citizensat-large to discuss and vent grievances on a sensitive topic that had long been politically taboo in the country. ${ }^{(15)}$ It even received backing from the state-run media, as People's Daily re-posted the film alongside an interview with Chai one day after the film's release, while Chen Jining, the newly appointed Minister of Environmental Protection, praised the film as "worthy of admiration." (16) Such unusual support from high-ranking officials, in addition to Chai's access to political elites in the film, raised suspicions that it was an orchestrated effort for some political factions to attack their enemies. Others criticised Chai's film as nothing but a cliché because it buried the most important social and political factors, attributing the smog problem to only economic and technological factors. ${ }^{(17)}$ Nevertheless, the opening was short-lived. The film's virality and the amount of discussion it generated prompted the propaganda authorities to order news units to discontinue coverage, including Chai's interview with the People's Daily, and all video portals to remove the film. Keywords related to the film have been blocked from microblogs since then.

\section{Women's rights and public health}

In another area of activism that has traditionally enjoyed some overlap with official discourse, at least ten feminist activists were detained ahead of International Women's Day on March 8. The arrests initially seemed to target a nationwide campaign against sexual harassment on public transportation on that day, when feminist activists had planned to distribute leaflets and post stickers on public transit. (18) Unlike previous crackdowns in which arrests usually targeted particular organisations or individuals, this time the crackdown was a coordinated effort against an activist network across the country. Most of the detained activists were released after being interrogated, but five remained in detention in three Chinese cities - Beijing, Hangzhou, and Guangzhou. The arrests drew widespread attention. Foreign governments and human rights groups called for the women's release, and a \#FreeTheFive campaign was initiated on social media to solicit public support globally. Support for the detained activists even came from within China, as academics echoed their cause and students signed petitions demanding their immediate release.

Given that feminist or anti-discrimination activism does not have overt political motives and had been largely tolerated by the state authorities in the past, the latest crackdown appeared to be a curious move. One feminist activist believed that the repression was not related to the action itself, but was instead an expression of the government's will to crack down on a series of former actions that attracted public attention, and hence warranted government repression. ${ }^{(19)}$ Others said that public security officials had been alarmed by the activists' "skillful use of social media to organize volunteers, their links to foreign organizations, and the inventive protests and flash mobs that often drew favorable coverage in the Chinese media," which have yielded measurable results, including a landmark bill on domestic violence. ${ }^{(20)}$ However, while the five activists were still under detention, the raid of the Beijing office of Yirenping 益仁平, a prominent public health and anti-discrimination NGO that has been championing gender equality and often employs litigation to fight discrimination, showed that the target was after all not just feminist activism. On 24 March, a score of men dressed in police uniforms raided the NGO's Beijing office, confiscating its computers and documents while locking employees out of the building. It appeared that the crackdown on Yirenping was connected with its support for feminist activism since 2012, including a series of performance art actions, as Yirenping's co-founder Lu Jun said in a statement. (21)

Nevertheless, Chinese gender scholar Wang Zheng believed that the ultimate target for the series of crackdown was Yirenping rather than the feminist activists. In an interview, she said that "the authorities probably don't want to make too big a splash by arresting the head of Yirenping, so they detained these young women to send the message." (22) In an interview with China Digital Times, however, Lu Jun said it was unclear whether the detention of the five feminists was targeting Yirenping, but he was certain that the NGO was not the only target of the crackdown. ${ }^{(23)}$ Whichever the authorities might be targeting, the high-profile raid of Yirenping, which occurred as the International Olympic Committee was considering Beijing's bid to host the 2022 Winter Olympics, (24) demonstrated that the government had either decided to ignore international reactions or underestimated

14. Mark Tran, "Phenomenal success for new film that criticises China's environmental policy," The Guardian, 2 March 2015, www.theguardian.com/world/2015/mar/02/china-environmental-policy-documentary-under-the-dome-chai-jing-video (accessed on 25 June 2015).

15. Tang Yinghong, "Chai Jing de wumai yanjiang shipin weishenme neng chuangzao chu xianxiang ji chuanbo jilu" (Why could Chai Jing's documentary create a phenomenal record?), https://mp.weixin.q9.com/s? biz=MjM5NzYzNzl5NA==\&mid=203546256\&idx=1\&sn=9a7a3c 7e980b371a3b74a899b73850 d7\&scene=2\&from=timeline\&isappinstalled=0\&key=8ea74966bf 01cfb6dbf6006382d77605578ae19d7554e9c8ad2aea8e9197b51413e6089ae7f84c9456d280d5 27c31375\&ascene $=2 \&$ uin=NjUwNjg5Njl0\&devicetype $=$ PPhone+OS8.1.3\&version=16010112\&f ontScale=100\&pass_ticket=RcEPO5PgN6NIHII7dBZnCHklzaGhmcYJB9uAuVU30srl3NMxeWn6X FhrSjcglJBg (accessed on 4 July 2015).

16. Gabriel Wildau, "Smog film captivates Chinese internet," Financial Times, 2 March 2015, www.ft.com/intl/cms/s/0/de190a92-c0b0-11e4-876d-00144feab7de.html\#axzz3e34GDfDh (accessed on 25 June 2015)

17. Tang Yinghong, "Chai ling de wumai yanjiang shipin weishenme neng chuangzao chu xianxiang ji chuanbo jilu" (Why could Chai Jing's documentary create a phenomenal record?), art. cit.

18. "China detains feminist activists over International Women's Day," The Guardian, 9 March 2015, www.theguardian.com/world/2015/mar/09/china-detains-feminist-activists-over-internationalwomens-day (accessed on 6 July 2015).

19. "Gender War \& Social Stability in Xi's China: Interview with a Friend of the Women's Day Five," Chuang, 18 March 2015, http://chuangcn.org/2015/03/gender-war-social-stability-in-xis-chinainterview-with-a-friend-of-the-womens-day-five-1st-half (accessed on 4 July 2015).

20. Andrew Jacobs, "Taking Feminist Battle to China's Streets, and Landing in Jail," The New York Times, 5 April 2015, www.nytimes.com/2015/04/06/world/asia/chinese-womens-rights-activists-fallafoul-of-officials.html (accessed on 25 June 2015).

21. Lu Jun, "Anti-Discrimination NGO Beijing Yirenping Center searched by 'policemen' while advocating for the release of five feminist activists," Beijing Yirenping Center, 25 March 2015, http://chinaaidsgroup.blogspot.hk/2015/04/china-aids8208-many-more-women-face.html (accessed on 25 June 2015). Lu Jun was visiting in the United States at the time of the crackdown, where he remains for the time being.

22. "Detention of Five Chinese Feminist Activists at the Juncture of Beijing+20 - An Interview with Gender Scholar Wang Zheng," China Change, 11 April 2015, http://chinachange.org/2015/04/12/ detention-of-five-chinese-feminist-activists-at-the-juncture-of-beijing20-an-interview-with-professor-wang-zheng (accessed on 25 June 2015).

23. "Lu Jun: One More Law Won't Make Us Helpless," China Digital Times, 16 July 2015, http://chinadigitaltimes.net/2015/07/lu-jun-one-more-law-wont-make-us-helpless (accessed on 19 July 2015).

24. William Wan, "China raids NGO offices in latest sign of crackdown on dissent," The Washington Post, 26 March 2015, www.washingtonpost.com/world/china-raids-ngo-offices-in-latest-sign-ofcrackdown-on-dissent/2015/03/26/4badeaac-d3b0-11e4-ab77-9646eea6a4c7_story.html (accessed on 4 July 2015) 
the impact of its action. Pressured by international pleas, the Chinese government eventually released the five activists after detaining them for more than a month, just before official charges had to be made. ${ }^{(25)}$ But the release was conditional, and the government retained a hard-line position against Yirenping. Not only did the foreign ministry spokesman state publicly in mid-April that the NGO "had violated the law and will be punished," security officials continued the crackdown on related activists. In early June 2015, human rights activists and former Yirenping employees Guo Bin and Yang Zhanqing were detained in Shenzhen and Huizhou respectively on charges of "illegal business operation." (26)

\section{Lawyers}

Just as Guo and Yang were released after one month of detention, public security authorities launched yet another large-scale crackdown on activists - this time on rights lawyers. The crackdown began on 9 July and continued over the next few days, when nearly 200 Chinese lawyers and activists were detained or questioned by the police or went into hiding. ${ }^{(27)}$ At the heart of the operation was the Beijing Fengrui Law Office, a law firm specialised in rights cases, where at least five employees, including three prominent rights lawyers, were taken away by the Beijing police or went missing. The firm is the former employer of activist Wu Gan, nicknamed "Super Vulgar Butcher" (chaoji disu tufu 超级低俗屠夫), who has been charged with "inciting subversion." Wu was believed to be targeted for drawing public attention to the May 2015 Qing'an Incident, in which the deadly police shooting of a young man triggered wide public discussion and calls for an independent investigation, as well as a petition signed by more than 700 lawyers demanding the release for six lawyers detained in Qing'an. (28) The Ministry of Public Security issued a statement on 11 July charging the group, led by the Fengrui Law Firm, labelled a "criminal syndicate," of disrupting public order and seeking profits by illegally hiring protesters and swaying court decisions in the name of "defending justice and public interests." (29) People's Daily also ran a long report detailing the allegations, while two Fengrui employees made confessions on state-run CCTV, admitting to being paid and paying others to hype sensitive cases. Similar to the arrests of the feminist activists, the crackdown on rights lawyers was also a nationwide campaign. Yet, with almost 200 targeted across China, the scale of repression was much larger and quite unprecedented. The operation appeared to be more concerted and high profile than previous crackdowns, as the arrests were immediately followed by a media campaign to associate the detainees with a "criminal gang."

\section{Legal restrictions on foreign NGOs}

While ad hoc repression continues against civil society activists and organisations, there are signs that a more comprehensive control of civil society activities is emerging. In December 2014, the Chinese government proposed a new law in the legislature that aims at regulating foreign NGOs operating in China. Proposed along with a draft National Security Law amidst President Xi's call for the promotion of rule of law, ${ }^{(30)}$ the draft Foreign NGO Management Law, which consists of nine chapters and 67 articles as of its second reading draft, establishes procedures for foreign-based nonprofit organisations to register formally and conduct activities in China. The proposed law follows a recent trend among countries such as India and Russia that have enacted laws restricting foreign funding of NGOs, partly to forestall foreign threats against national security. ${ }^{(31)}$ The Chinese law was motivated by a similar purpose. It places foreign NGOs in China as well as their temporary activities under greater state scrutiny, requiring them to be sponsored by a professional supervisory unit (PSU) authorised by the government and also to be registered with a registration management organ (RMO), i.e., the local public security bureau, before conducting activities in China. Activities with a duration of less than a year require temporary activity permits from PSUs or state organs, or Chinese partners approved by the public security authorities. To a certain extent, the requirement of registration and supervision resembles the dual registration of domestic NGOs, a system that has been gradually abolished in recent years, contributing to a surge of domestic NGOs. The new draft law, on the contrary, appears to be a step backwards for foreign counterparts.

There are at least a few problems worth highlighting in the impending law. First is the law's expansive and limitless coverage. The word foreign, or jingwai 境外, is referred to as extra-jurisdictional, and includes not only foreign countries, but also areas with special and controversial status, namely Hong Kong, Macau, and Taiwan. The term "NGO," or fei zhengfu zuzhi 非政 府组织, is defined in the law expansively as "non-profit, non-governmental social organisations," meaning that even universities, professional associations, and interest groups would fall within the scope. In addition, while the law applies to their "activities," or huodong 活动, within the territory of China, the term is left undefined, which in effect allows it to encompass anything. Second is that these vaguely-defined terms would give rise to varying legal interpretations and the exercise of discretionary powers by the authorities. For instance, Article 59 lists several circumstances in which registration of foreign NGOs would be revoked and the person-in-charge could be detained, including "the subversion of state power," "undermining ethnic harmony," "engaging in separatism," "inciting resistance against enforcement of state law or administrative regulations," "gathering state secrets or intelligence," and any "other activity that either endangers state security or damages the national or public interest," etc. While these span a broad range of potential offences, the last item covers anything that could be interpreted by the authorities as "national or public interest." Third is the transfer of registration from the civil affairs to public security departments. This would not just expand the scope of stability maintenance (weiwen 维 稳) and the jurisdiction of the public security organs, but also generate immense police powers, such as the searching of representative offices, seizure of materials, and detention of representatives without warrant. Furthermore, it would also diminish the grey zone in which foreign NGOs were tacitly

25. "Chinese police release feminist activists," The Guardian, 13 April 2015, www.theguardian.com/ world/2015/apr/13/chinese-police-free-three-of-five-feminist-activists (accessed on 6 July 2015).

26. Tom Philips, "Fears of new crackdown as China holds two former members of rights group," The Guardian, 15 June 2015, www.theguardian.com/world/2015/jun/15/china-detains-two-formermembers-of-human-rights-group-guo-bin-yang-zhanqing (accessed on 25 June 2015).

27. Chris Buckley, "Chinese Authorities Detain and Denounce Rights Lawyers," The New York Times, 11 July 2015, www.nytimes.com/2015/07/12/world/asia/china-arrests-human-rights-lawyerszhou-shifeng.html?ref=asia (accessed on 16 July 2015).

28. Verna Yu, "Formal arrest of Chinese activist 'Super Vulgar Butcher' for 'inciting subversion' approved," South China Morning Post, 4 July 2015, www.scmp.com/news/china/society/ article/1832597/chinese-online-activist-super-vulgar-butcher-set-formal-arrest (accessed on 16 July 2015).

29. "China apprehends suspected paid protest organizers," Xinhua, 12 July 2015, http://news.xinhuanet.com/english/2015-07/12/c_134405003.htm (accessed on 16 July 2015).

30. "Xi calls for rule of law, deepening reforms," Xinhua, 27 October 2014, http://news.xinhuanet.com/ english/china/2014-10/27/c_133746407.htm (accessed on 25 June 2015).

31. "Uncivil societies," The Economist, 13 September 2014, www.economist.com/news/leaders/ 21616952-illiberal-governments-are-blocking-activists-receiving-foreign-cash-liberal-onesshould-not (accessed on 3 July 2015). 
sanctioned by the state authorities to operate, which was partly due to the lack of legal provision. ${ }^{(32)}$ With the legislation of a formal law, such space for toleration will officially diminish.

Fourth, the requirement for dual registration not only creates multiple and overlapping layers of authority, but also extra administrative constraints and burdens. Article 24 and Article 37 respectively require foreign NCOs to submit an annual activity plan and an annual report to both the PSU and RMO, but the level of detail required by them and the flexibility they allow remain unclear. If all activities are required to be reported in the plan, it will constrain the flexibility of foreign NGOs to respond to emergencies or act on windows of opportunity, not to mention additional administrative work. Articles 26 and 27 limit their sources and use of funding, prohibiting fundraising and acceptance of donations within China while requiring them to use funds from registered bank accounts, or those from their Chinese partners if they are on temporary permits. Articles 32 to 35 make requirements for personnel arrangements, under which foreign NGOs cannot develop membership and must recruit local staff and volunteers through an intermediary management agency. While these rules give both the PSU and public security authorities broad powers and discretion to keep track of and influence their activities, grant-attribution, and personnel decisions, articles 45 to 51 would also grant them unrestricted access to their offices, computers, and bank accounts. Violations of the law, which are handled by the public security organs alone and do not require court rulings, would be liable to warnings, confiscations, withdrawal of registrations and permits, fines, or even administrative detention for up to 15 days. With the broad scope of the law and the new responsibilities taken up by the PSUs and RMOs, one question would be whether the state organs responsible for registration and supervision will have the capacity and manpower to take up the extra administrative work. The sudden increase in workload, in addition to the decentralised implementation by local governments, might after all lead to selective and arbitrary enforcement of the law. This would undermine rather than strengthen the rule of law as intended by the act of legislation.

But the greatest impact of the law will be on the survival and local partnership of foreign NGOs. In order for foreign NGOs to maintain their foothold in China, many might choose to avoid projects in areas that the authorities deem sensitive, such as those involved in rights and labour issues. In addition, as noted by Professor Chan Kin-man, a sociologist at the Chinese University of Hong Kong, the layers of supervision required by the law would stifle international NGO cooperation with domestic partners, and registered foreign NGOs could get into trouble for working with unregistered domestic partners. ${ }^{(33)}$ On the other hand, it might encourage self-censorship among foreign organisations with connections to China. For instance, foreign universities, which would be included in the law, might censor their academic or student activities to avoid antagonising the Chinese government so that student admissions, exchange programs, partnership with schools, or satellite campuses in China would not be affected. The repercussions also reach well beyond foreign NGOs. Article 38, for instance, says that "individuals, legal persons, and other organisations within mainland China may not accept commissions and funds from foreign NGOs that have neither registered a representative office nor obtained a temporary activity permit, or represent or covertly represent the non-mainland NGOs in conducting activities." This would mean that grassroots NGOs in China, many of which are involved in a broad range of issues from the environment to human rights and are supported by foreign funding and training, can no longer be financially sponsored by unregistered foreign organisations. The withdrawal of these foreign partners from China would certainly curtail the funding and knowledge transfer on which domestic NGOs heavily rely.

Chambers of commerce and business groups were also deeply concerned about the implications of the draft law on foreign business activities in China. Most notably, a group of 45 U.S. business and professional organisations, representing various industries, signed a letter urging the Chinese government to modify the draft law. ${ }^{(34)}$ The letter argued that the scope of the law is too broad, as the definition of NGO would encompass trade associations, overseas chambers of commerce, professional associations, universities, and environmental organisations, which play an integral part in the daily operations of foreign companies. It also raised concerns that the law put management of these groups under the public security organs, which might severely impact commercial activities and business operations. Nevertheless, there were others who believed that the draft law was not as negative as has been argued. Writing in a ChinaFile conversation, Taisu Zhang, a legal scholar at Duke University, argued that the draft legislation might not represent a serious deterioration in the legal status of foreign NGOs because "[t]he specter of arbitrary police interference and highly ambiguous administrative review has always hung over foreign NCOs." On the contrary, the law would instead "eliminate some of the ambiguity surrounding issues such as registration, and does not seem to either add or subtract significantly from the amount of power wielded by public security organs." Although he agreed with the possibility of a social chilling effect, it would still lower the administrative costs of operating in China, "insofar as it provides a somewhat clearer roadmap of the legal and administrative hurdles that one must overcome." (35) While Zhang might be right from a legalist perspective in arguing that clearer rules lower administrative costs, he seemed to be less concerned about how the content of the law might raise operating costs, given the burdensome procedures of registration and supervision, and the possible imposition of external costs on domestic civil society if foreign partners decide to reduce or withdraw their operations.

Ultimately, the most questionable aspect of the law is the legislative intent. As Tsinghua University scholar Jia Xijin says, it is rather unnecessary, from a legal perspective, to separate the management of foreign NGOs from domestic ones, namely social organisations (shehui tuanti 社会团体), private non-enterprises (minban feiqiye 民办非企业), and foundations (jijinhui 基金会) - all of which are already governed by corresponding laws. The imperative to identify foreign NGOs as a distinct category, governed by a separate set of rules, is hence reflective of the Chinese government's profound unease over their threat to national security, an area in which a separate law is being legislated in parallel. If the objective of legislation is to safeguard national security, jia argues, it would be more appropriate to enact a conduct-based law as opposed to one based on whether organisations are foreign or not. No amendment could eliminate or lessen such an existential concern. But if the legislation were to proceed according to plan, at least one amendment, as suggested by Jia, seems necessary: the law

32. Jennifer YJ Hsu and Reza Hasmath, "The Local Corporatist State and NCO Relations in China," Journal of Contemporary China, Vol. 23, No. 87, 2014, pp. 516-534.

33. Verna Yu, "Draft Chinese law puts NGOs' future on the line," South China Morning Post, 4 June 2015, www.scmp.com/news/china/policies-politics/article/1816097/draft-chinese-law-puts-ngos-future-line (accessed on 25 June 2015).

34. Gillian Wong, "U.S. Business, Professional Groups Sign Letter Opposing Draft China NGO Law," The Wall Street Journal, 4 June 2015, www.wsj.com/articles/u-s-business-professional-groupssign-letter-opposing-draft-china-ngo-law-1433440263 (accessed on 25 June 2015).

35. Taisu Zhang, blog entry in "The Future of NGOs in China," The ChinaFile, 15 May 2015, www.chinafile.com/conversation/future-ngos-china (accessed on 25 June 2015). 
needs to include an appeal process for rejections and non-approvals.

Although the second draft has relaxed stipulations to allow foreign NGOs to open branch offices with the State Council's permission, in order to accommodate the fact that many science- and technology-related foreign NGOs already have branch offices, ${ }^{(36)}$ the content remained largely unchanged from the first draft, and is not expected to include drastic changes in its third revision before proceeding to final approval in the legislature, which is expected by the end of 2015. On 1 July, the National People's Congress enacted the National Security Law, extending state security power across a wide spectrum, from cyberspace to the outer space. Another draft law on counter-terrorism is also under consideration.

While domestic NGOs now face being cut off from their foreign partners, the Chinese government is proposing new regulations to strengthen Party control over them. A new Politburo directive released in June 2015 has stressed the need to establish a Party members' group in all domestic social organisations alongside state organs and state-owned and private enterprises, a move that was said to reflect the Party's anxiousness to bolster its authority across society. ${ }^{(37)}$ Central Party School professor Zhang Xixian said that the continued growth of domestic NGOs had prompted the central government to require them "to establish Party groups in order to better guide their development," as they are "more focused on directly leading the organization to follow the core values of the Communist Party." (38) Previously, all social organisations were permitted to establish Party member groups, but now they will be required to do so, although the exact measures are not yet clear.

\section{Conclusion}

For now, China's civil society is unlikely to inject new impetus into political reform. As the recent spate of crackdowns on civil society activists under the Xi administration shows, the space for moderate, reformist civic participation has been shrinking, and relaxation has become an exception rather than part of an alternate cycle. With a new foreign NGO law in sight, the practice of ad-hoc repression, which often leads to backlashes from both within and abroad, will be complemented by a more systematic legal code that sophisticates the Party's control over civil society activities connected to foreign non-profits. The new Party directive ordering domestic social organisations to set up Party members' groups will similarly extend the Party's reach over the expanding local civil society landscape.

The only reason to be optimistic is that China's resilient civil society is constantly adapting to avoid crackdowns and circumvent barriers. For instance, the feminist movement, which comprises a loose network of activists and intellectuals and makes use of the Internet and social media to advance their causes and connections, suggests the emergence of a form of network-based civil society rather different from the conventional form based on NGOs and individual activists. The absence of formal organisational structure, and the fact that no single representative can be held responsible, gives a lot of flexibility and fluidity to these civil society networks, hence making them much more difficult to track and crack down on. While these will generate new dynamics of civic participation, the changes, in light of the Party's stronger grip and new restrictions, will certainly be slow, protracted, and subtle.

I Samson Yuen is a PhD candidate in politics at the University of Oxford and is a research assistant at the CEFC

(samson.yuen@sant.ox.ac.uk).

CEFC News Analysis is compiled from the CEFC's fortnightly selection of Press Highlights, available at www.cefc.com.hk.
36. "Draft law to protect overseas NGOs in China," Xinhua, 20 April 2015, http://news.xinhuanet.com/ english/2015-04/20/c_134165975.htm (accessed on 25 June 2015).

37. "Communist Party seeks to bolster authority with new rule for branches across China," South China Morning Post, 30 May 2015, www.scmp.com/news/china/policies-politics/article/ 1813133/communist-party-seeks-bolster-authority-new-rule (accessed on 25 June 2015); on PONGOs (Party-organised NCOs) see also the following article: Patricia Thornton, "The Advance of the Party: Transformation or Takeover of Urban Grassroots Society?," The China Quarterly, No. 213, 2013, pp. 1-18.

38. "Zhonggong zhongyang mingque zai shehui zuzhi lingdao jiguan zhong sheli dangzu" (Party Central clearly vowed to establish Party members' groups in social organisations), Xinhua, 30 May 2015, http://politics.people.com.cn/n/2015/0530/c70731-27078843.html (accessed on 3 July 2015). 